\title{
МЕХАНІЗМ РЕАЛІЗАЦІЇ ПОРТФЕЛЬНО-ОРІЕНТОВАНОГО УПРАВЛІННЯ ЗБАЛАНСОВАНИМ РОЗВИТКОМ ОРГАНІЗАЦІЙ ПЕРЕВІЗНИКІВ АВТОМОБІЛЬНОГО ТРАНСПОРТУ
}

\author{
Білоног O.C., Національний транспортний університет, Київ, Україна, \\ bilonog.oksana@gmail.com, orcid.org/0000-0003-2471-5388 \\ Третиниченко Ю.О., Національний транспортний університет, Київ, Україна, \\ tpsalkaf@ntu.edu.ua, orcid.org/0000-0002-3797-9035 \\ Срібна Н.В., Національний транспортний університет, Київ, Україна, natasribna28@gmail.com, \\ orcid.org/0000-0002-7543-2997 \\ Параніч П.Г., Національний транспортний університет, Київ, Україна, pparanich@ukr.net, \\ orcid.org/0000-0002-1029-3535
}

\section{THE IMPLEMENTATION MECHANISM FOR PORTFOLIO MANAGEMENT OF THE BALANCED DEVELOPMENT OF ROAD TRANSPORT COMPANIES}

Bilonog O.Ye., National Transport University, Kyiv, Ukraine, bilonog.oksana@gmail.com, orcid.org/0000-0003-2471-5388

Tretynychenko Yu.A., National Transport University, Kyiv, Ukraine, tpsalkaf@ntu.edu.ua, orcid.org/0000-0002-3797-9035

Sribna N.V., National Transport University, Kyiv, Ukraine, natasribna28@gmail.com, orcid.org/00000002-7543-2997

Paranich P.H., National Transport University, Kyiv, Ukraine, pparanich@ukr.net, orcid.org/00000002-1029-3535

\section{МЕХАНИЗМ РЕАЛИЗАЦИИ ПОРТФЕЛЬНО-ОРИЕНТИРОВАНОГО УПРАВЛЕНИЯ СБАЛАНСИРОВАНЫМ РАЗВИТИЕМ ОРГАНИЗАЦИЙ ПЕРЕВОЗЧИКОВ АВТОМОБИЛЬНОГО ТРАНСПОРТА}

Билоног O.E., Национальный транспортный университет, Киев, Украина, bilonog.oksana@gmail.com,orcid.org/0000-0003-2471-5388

Третиниченко Ю.А., Национальный транспортный университет, Киев, Украина, tpsalkaf@ntu.edu.ua, orcid.org/0000-0002-3797-9035

Срибна Н.B., Национальный транспортный университет, Киев, Украина, natasribna28@gmail.com,orcid.org/0000-0002-7543-2997

Паранич П.Г., Национальный транспортный университет, Киев, Украина, pparanich@ukr.net, orcid.org/0000-0002-1029-3535

Постановка проблеми. Об'єднання проектів і програм в портфелі дозволяє отримати нову якість управління ними, збільшити загальний ефект від їх реалізації, а самі портфелі на сьогодні поступово перетворюються на один із найбільш дієвих механізмів реалізації стратегій організаціями, незалежно від структурної конфігурації останніх.

Організації, які здійснюють доставку вантажів автомобільним транспортом із використанням термінальної технології (ДВАТТ), виходячи із характеру пропонованої ними послуги і використовуваної технології її виробництва (надання), можна розглядати як такі, що складаються із мережі географічно розподілених однорідних структурних одиниць. Клієнти i/або кінцеві споживачі таких організацій мають бути певні в тому, що на них очікують тотожні продукти (послуги), вартість і ставлення в будь-якій організаційній одиниці, із якою вони взаємодіють. За приклади таких організаційних одиниць, які працюють в рамках єдиної корпоративної структури, можуть розглядатися мережеві структури закладів швидкого харчування та роздрібної торгівлі, ресторанів, готелів, станцій заправки автомобілів тощо.

Водночас, слід вказати на значущу відмінність організацій ДВАТТ відносно наведених прикладів, яка полягає в існуванні взаємозв'язку між окремими структурними одиницями не лише через сумісно використовувані маркетингові системи i/або системи постачань, а й в рамках умов використання обраної термінальної технології доставки дрібних відправлень вантажів автомобільним транспортом. За даних обставин для організацій ДВАТТ особливої актуальності набуває проблема 
забезпечення, розглядуваного за різними аспектами, збалансованого розвитку виробничих процесів $\mathrm{i}$ систем. За останні для таких організацій виступають процеси і системи доставки вантажів автомобільним транспортом із використанням термінальної технології. Можна зробити припущення, що ефективне вирішення даної проблеми пов'язується із реалізацією портфельно-орієнтованого управління проектами і програмами розвитку процесів і систем доставки вантажів в організаціях ДВАТТ.

За даних умов актуальним науковим завданням, яке потребує подальших розвідок, $\epsilon$ розроблення науково-методичних основ портфельно-орієнтованого управління збалансованим розвитком організацій ДВААТ.

Огляд робіт. Умови стратегічно-орієнтованого управління організаціями ДВАТТ - як сукупністю однорідних територіальних організаційних структурних одиниць (ТОСО) - виходять із необхідності забезпечення збалансованості функціонування $\mathrm{i}$ розвитку останніх. Дану збалансованість, відповідно до розробленої авторами даної статті системної моделі стратегічного управління збалансованим розвитком організації ДВАТТ, пропонується оцінювати за наступною системою аспектів [1]: територіальним, який відповідає рівню управління територіальними організаційними структурними одиницями; процесним, виокремлюваним в складі територіального за процесами, який відповідає рівню управління територіально-процесними структурними одиницями; діяльнісним, який виокремлюється в складі процесного за діяльностями (видами діяльностей), що, за цитованою моделлю, узгоджується зі сферами (напрямами), які слідують концепції збалансованої системи показників (ЗСП) [2], і який відповідає рівню управління територіально-процеснодіяльнісними структурними одиницями.

В роботах [3, 7] розроблена структурна модель формування інтегрального показника для багатокритеріального оцінювання роботи ТОСО організацій ДВАТТ, рис 1. Разом із тим, при прийнятті управлінських рішень на основі даного інтегрального показника, зокрема інтерпретації отриманих значень часткових (вихідних) показників, які знаходяться на найнижчому рівні відповідної ієрархічної структурної будови даного показника [3], до уваги, без додаткових уточнень щодо використовуваних оцінок, шкал тощо, не може бути взята варіабельність процесів (підпроцесів), які ці часткові показники характеризують. Водночас, відповідно до ідеї концепції Демінга-Шухарта [4,5] результати будь-якого процесу характеризуються варіабельністю, тобто мають місце випадкові коливання. Таким чином, запропонований в роботах [6,7], інтегральний показник для багатокритеріального оцінювання роботи ТОСО організацій ДВАТТ отримав подальший розвиток в роботі [6], зокрема в частині можливості врахування умов варіабельності процесів (підпроцесів), які мають характеризувати обрані для використання часткові (вихідні) показники, і на основі яких (часткових показників), в свою чергу, із наданням їм відповідної ваги, і обчислюється вищезгадуваний інтегральний показник, рис.1

Виходячи з вищевикладеного, наукова прогалина ідентифікується в частині розроблення, на основі концепції портфельно-орієнтованого управління збалансованим розвитком виробничих процесів і систем, як процесів і систем доставки вантажів, в організаціях ДВАТТ, механізму реалізації портфельно-орієнтованого управління збалансованим розвитком організацій ДВАТТ. Вищезгадувана системна модель стратегічно-орієнтованого управління збалансованим розвитком організацій ДВАТТ [1] i модель інтегрального показника оцінювання виробничої збалансованості i формування збалансованого виробничого портфеля організацій ДВАТТ $[3,6,7]$ складають дану концепцію.

Постановка завдання. Метою даної роботи є розроблення механізму реалізації портфельноорієнтованого управління збалансованим розвитком транспортних процесів і систем в організаціях ДВАТТ.

Виклад основного матеріалу дослідження. Розглядаючи сумісно процеси і функціональні структури, які мають забезпечувати реалізацію даних процесів, в тому числі різних організацій, які складають організаційні мережі, не можна уникнути питання про умови взаємодії функціонального i процесного підходів в організаційному управлінні. На сьогодні, більшість організацій, які надають логістичні, в тому числі розглядувані в складі останніх транспортні, послуги, вибудовує свої організаційні структури на основі функціонального (адміністративно-ієрархічного) підходу. Це означає, що організаційна структура складається із підрозділів, ієрархічно підпорядкованих за функціональною ознакою. Така організаційна структура, як зазначається в науковій літературі, має багато недоліків, i, як вважає сучасна методологія управління, саме на подолання цих недоліків спрямовується процесний підхід. Сутність останнього, як відомо, полягає в тому, що в організації виокремлюється ряд бізнес-процесів, кожний із яких охоплює кілька структурних підрозділів (іноді навіть всі, особливо, коли мова йде про профільну діяльність) і метою якого є отримання деякого значущого для організації результату. 


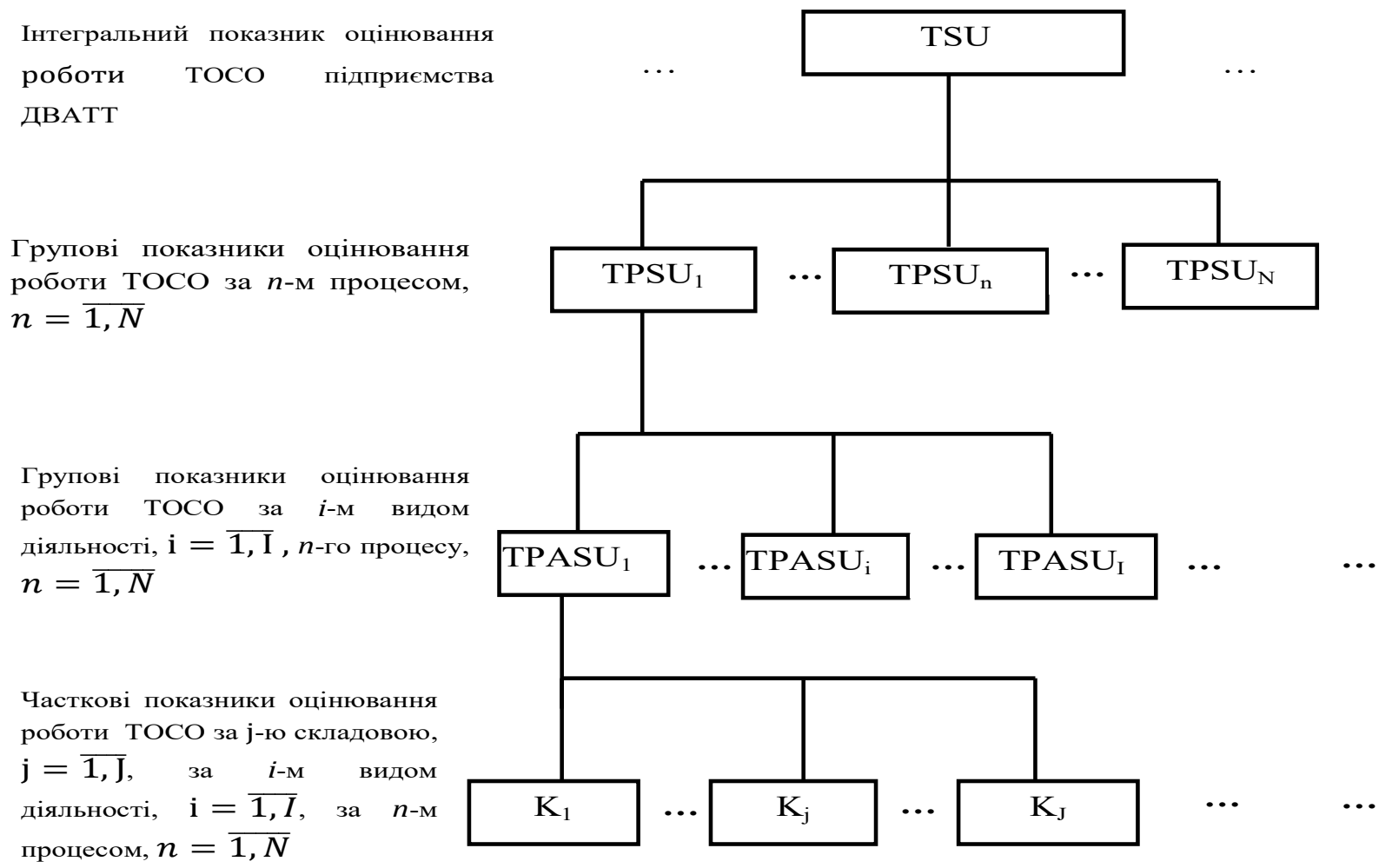
Рисунок 1 - Структура інтегрального показника для багатокритеріального оцінювання роботи ТОСО організацій ДВАТТ
Figure 1 - The structure of integral indicator for TOSU' multi criteria performance evaluation of organizations DGRTT

Кожна компанія має бізнес-процеси, які створюють вартість для споживача. Проте відносно незначна частина компаній розглядає їх як основний об'єкт стратегії. За коректної організації процесного підходу кожний процес має свого «господаря» («власника») і «команду», яка складається iз співробітників різних структур, які інтегровані в даний процес. Можна зауважити, що процесне управління багато в чому є аналогом до проектного. Відмінність - проект є заходом обмеженим у часі, спрямованим на досягнення певної кінцевої цілі, тоді як процес - це умовно-постійне, таке, яке регулярно повторюється у часі, явище. Організації процесного управління, як відомо, підтримуються встановленим нормативним і методичним забезпеченням, зокрема серією стандартів системи управління якістю. Разом із тим, не дивлячись на популярність, якої за останні роки набув процесний підхід, можна навести відносно невелику кількість прикладів його успішної реалізації. В роботі [8, c.21] вказується на дві основні причини, які, на думку авторів, обумовлюють існування такої ситуації. Перша причина полягає в тому, що достатньо не $є$ опрацьованими організаційні структури процесного управління. Друга причина пов'язана із тим, що далеко не завжди впровадження процесного підходу є дійсно виправданим. Сама по собі функціонально-ієрархічна структура, не дивлячись на всі ії недоліки, не є такою недосконалою. Вона звична, зрозуміла, має високу ступінь стійкості, а також повноту і завершеність із точки зору всіх аспектів управління (планування, контроль, будова організаційної структури, ресурсне забезпечення тощо). Процесне управління, само по собі, складніше, вимагає більших витрат і зумовлює виникнення бар'єрів між окремими процесами навіть в межах однієї організації. Єдина реальна цінність процесного управління полягає в можливості, зокрема на думку авторів цитованої роботи, ефективного досягнення поставлених цілей.

Представлена в табл.1 форма, яку ми визначаємо в даній роботі як матричну, для формування системи ключових показників комплексного оцінювання окремих процесів діяльності організаційних структур дозволяє, із одного боку, оцінювати ефективність досягнення глобальних (системних) цілей за відповідними процесами, а, з іншого, грунтуючись на результатах загального процесу, виявляти підпроцеси (операції), проведення змін в яких, як у «вузьких» місцях, може виявитися найбільш ефективним щодо покращення результатів загального процесу. Крім того, виявлення підпроцесів (операцій), які потребують змін, в рамках загального процесу можна зробити в спосіб, який дозволить «прив'язати» останні до певних структурних підрозділів організації, які забезпечують дані 
підпроцеси в організації - окремо або у взаємодії із іншими учасниками (наприклад, для організацій ДВАТТ при прийнятті або передачі відправлення, контактуючи із клієнтом, тощо). Або, навпаки, реорганізувати будову організаційної структури, слідуючи умовам виокремлення підпроцесів (операцій). Виокремлення груп показників щодо реалізації стратегії відбувається відповідно до концепції збалансованої системи показників (ЗСП) [2].

Відповідно, формуючи, в рамках пропонованого концептуального підходу, системи ключових показників для оцінювання діяльності за визначеними структурними підрозділами, можна забезпечити стратегічну орієнтованість останніх - як на цілі «своєї» організації, так і загального процесу, до забезпечення якого вони залучаються, і створити можливості до підвищення ступеня узгодженості даних цілей і приймаємих рішень, кооперації між структурами, залучуваними до виконання окремих підпроцесів (операцій), тощо. Також, як можна очікувати, умови формування даної системи показників створюють можливості до забезпечення логістичними провайдерами, залучуваними на засадах аутсорсингу, наприклад, при завезенні i/aбо вивезенні відправлень із терміналів в організаціях ДВАТТ, параметрів послуг, які клієнти бізнесових підприємств виокремлюють як найбільш важливі, поряд із ціною, - здатність задовольняти вимоги, обслуговуваних ними клієнтів щодо терміну, місця чи способу доставки; креативний підхід до розв'язання проблем; репутація щодо забезпечення неперервного покращення; усвідомлення значущості відносин із окремими клієнтами [9]. Пропонований концептуальний підхід до формування системи ключових показників комплексного оцінювання окремих підпроцесів і організаційних структур може бути реалізовано в організаціях ДВАТТ за умов забезпечення співставимості процесів (операцій). Очевидно, що останнє не завжди є можливим. Запровадження даної концепції формування матричних структур для розроблення систем ключових показників комплексного оцінювання окремих процесів і діяльності структурних підрозділів, які їх забезпечують, є можливим як в межах однієї організації, яка реалізує відповідний процес як профільну для себе діяльність, в тому числі впроваджуючи стратегію інтеграції щодо процесу ланцюга постачань i/aбо логістичного ланцюга, так i в умовах слідування кількома організаціями концепції управління ланцюгами постачань $\mathrm{i}$ запровадження партнерських відносин між підприємствами-учасниками.

Наведена форма, табл.1, для розроблення ключових показників оцінювання процесів i окремих організаційних структур або центрів відповідальності (ЦВ), які мають забезпечувати ці процеси, виходить, аналогічно до матричних організаційних структур, із наявності не одного, а двох (іноді, можливо, більше) каналів (контурів) управління, наприклад, процесного і функціональноієрархічного або проектного і функціонально-ієрархічного.

Таблиця 1 - Концептуальний підхід до формування системи ключових показників оцінювання процесів і організаційних структур, які їх забезпечують

Table 1 - Conceptual approach to creation of the system of key indicators for evaluation of processes and organizational structures which maintain them

\begin{tabular}{|c|c|c|c|c|c|}
\hline \multirow[b]{2}{*}{$\begin{array}{c}\text { Підпроцес } \\
\text { за } \\
\text { загальним } \\
\text { процесом }\end{array}$} & \multicolumn{4}{|c|}{ Множина показників за m-ю групою ЗСП реалізації стратегії } & \multirow[b]{2}{*}{$\begin{array}{l}\text { Множина організаційних } \\
\text { структур (ЦВ), яка } \\
\left.\text { забезпечує підпроцес ( } \mathrm{S}_{\mathrm{i}}\right)\end{array}$} \\
\hline & $\begin{array}{c}\text { задоволення потреб } \\
\text { (очікувань) клієнтів } \\
\text { i/aбо споживачів, } \\
\text { m=1 }\end{array}$ & $\begin{array}{c}\text { внутрішні } \\
\text { бізнес- } \\
\text { процеси, } \\
\text { m=2 }\end{array}$ & $\begin{array}{c}\text { фінансова } \\
\text { результативність, } \\
\text { m=3 }\end{array}$ & $\begin{array}{c}\text { інноваційність, } \\
\text { навчання та } \\
\text { розвиток } \\
\text { персоналу, } \mathrm{m}=4\end{array}$ & \\
\hline $\mathbf{p}_{1}$ & $\mathrm{~K}_{\mathrm{P} 1} 1 \leftarrow \longrightarrow$ & $\mathrm{K}_{\mathrm{P} 1} 2 \leftarrow-$ & $-K_{P 1} 3 \leftarrow$ & $\mathrm{K}_{\mathrm{P} 1} 4 \leftarrow-$ & $\mathbf{S}_{1}$ \\
\hline 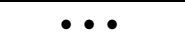 & •.• & $\cdots$ & $\cdots$ & $\cdot \cdots$ & •. \\
\hline $\mathbf{p}_{\mathbf{i}}$ & $\mathrm{K}_{\mathrm{P} 1} 1 \leftarrow-$ & $\underset{\mathrm{K}_{\mathrm{P} 1} 2 \leftarrow-}{\rightarrow \mathrm{K}_{\mathrm{Si}} 2}$ & $\mathrm{~K}_{\mathrm{P} 1} 3 \leftarrow-$ & $\mathrm{K}_{\mathrm{P} 1} 4 \longleftarrow-$ & $\mathbf{S}_{\mathbf{i}}$ \\
\hline •.・ & -.・ & $\cdots$ & $\cdots$ & -. & -.・ \\
\hline $\mathbf{p}_{\mathbf{I}}$ & $\mathrm{K}_{\mathrm{PI}} 1 \leftarrow-\longrightarrow \mathrm{K}_{\mathrm{SI}} 1$ & $\underset{\mathrm{K}_{\mathrm{PI}} 2 \leftarrow-}{\longrightarrow \mathrm{K}_{\mathrm{SI}} 2}$ & $\rightarrow \mathrm{K}_{\mathrm{SI} 3}$ & $\mathrm{~K}_{\mathrm{PI} 4 \leftarrow-}$ & $\mathbf{S}_{\mathbf{I}}$ \\
\hline $\begin{array}{l}\text { Загальний } \\
\text { процес (Р) }\end{array}$ & $K_{1 p}$ & $\mathbf{K}_{2 p}$ & $\mathbf{K}_{3 p}$ & $\mathbf{K}_{4 \mathbf{p}}$ & $\begin{array}{c}\text { Загальна структура - } \\
\text { ланцюг постачань, } \\
\text { логістичний ланцюг, } \\
\text { організація тощо (S) }\end{array}$ \\
\hline
\end{tabular}


Водночас, в даній роботі ми виходимо із можливості, в загальному випадку, об'єднання в забезпечені процесів різних організацій, наприклад, транспорту, які складають ланцюги постачань, логістичні ланцюги тощо. Звідси, постає питання щодо дієвості каналу процесного управління відносно окремих організацій. Крім припущення про існування на конкурентних ринках джерела влади у відносинах «постачальник - клієнт (споживач)» на користь останнього, в тому числі така ситуація можлива і щодо внутрішнього клієнта, на дієвість каналу процесного управління також має впливати характер відносин між організаціями, які можуть суттєво різнитися, навіть, за умов привнесення до відповідних ланцюгів концепції управління ними як цілісними системами. Зауважимо, що проблематика типології партнерств і того, яким чином тип партнерства впливає на забезпечення функцій управління в організаціях, які складають дані партнерства, стала предметом багатьох досліджень. Так, в роботі [10], а також в інших іiі варіантах, зокрема [11, с.9-30], в рамках пропонованої в ній моделі партнерства, тип партнерства (розглядаються три типи) встановлюється залежно від балів, отриманих за значущістю рушіїв до партнерства - ефективність (економічність) активів i/aбо витрат, підвищення якості обслуговування клієнтів (споживачів), ринкові переваги, ріст i/aбо стабільність прибутків, а також факторів, які сприяють партнерству - основних (сумісність корпоративних культур, сумісність філософії та методів управління, відчуття спільності та співставимість підприємств) і додаткових (спільні конкуренти, близькість розташування, можливість роботи на умовах ексклюзивності, успішність попереднього досвіду співпраці, спільні кінцеві клієнти та/або споживачі).

В свою чергу, залежно від типу партнерства, встановлюються вимоги до складових (компонентів) партнерства [11, с.9-30]. Реалізація вимог партнерств, відносно вищого рівня, тобто типу 2 і 3, зокрема щодо планування, контролю за спільною діяльністю, забезпечення комунікацій, за визначенням дозволяє впровадити пропонований концептуальний підхід до формування системи ключових показників комплексного оцінювання процесів і діяльності окремих організаційних структур у відповідних міжорганізаційних відносинах. Теж можна зазначити, із деякими застереженнями, i щодо партнерства типу 1 , проте це потребує уточнення відповідних процедур.

Можна зробити припущення, що підвищення ефективності процесного управління в сфері транспортного обслуговування може бут досягнуто за рахунок реалізації портфельного управління за процесами. При цьому портфелі можуть структуруватися в різний спосіб - за процесом в цілому, за підпроцесами тощо. Такий підхід, зокрема, знижує залежність результативності і економічності управління від використовуваної підприємством організаційної моделі, а також інших факторів внутрішнього і зовнішнього середовища. Водночас, даний підхід може використовуватись як власне в умовах реалізації процесного управління, подолавши вищезазначені недоліки останнього, так i розглядатися як ефективний «засіб» переходу до процесного управління.

В контексті аналізу умов функціонування та розвитку організацій ДВАТТ можна рекомендувати структурувати портфелі (підпортфелі) за процесами (підпроцесами) загального процесу. Тобто, можна вести мову про портфельно-орієнтоване управління процесом. Із одного боку, це, як можна очікувати, створить об'єктивні передумови до стандартизації вимог до параметрів надаваємих за відповідними процесами (підпроцесами) послуг в межах всієї організації ДВАТТ i, на основі концепції збалансованого розвитку останніх, раціонального розподілу ресурсів, а із іншого забезпечить ефект синергії в умовах реалізації однотипних проектів і програм, спрямованих на вдосконалення однойменних процесів, які знаходяться в сфері відповідальності різних ТОСО. Це $\epsilon$ передумовою до подальшої перебудови системи управління організацією ДВАТТ в такий спосіб, щоб розглядати виокремлювані за ТОСО однойменні процеси (підпроцеси) в рамках єдиного процесу, долаючи, таким чином, бар'єри, зумовлені дією територіального (регіонального) чинника, - як чинника визначення структурного підпорядкування.

«Ланцюг є настільки надійним, наскільки є надійною найслабкіша ланка, яка його складає». Якщо застосувати цю тезу відносно організації ДВАТТ, то «надійність» визначається як горизонтальною структурою однойменних підпроцесів - як ланок, які знаходяться в сфері відповідальності окремих ТОСО, так і вертикальною структурою послідовних, i, відповідно, різнойменних підпроцесів - як ланок, які знаходяться в сфері відповідальності окремих ТОСО, а, за умов наявності сумісного управління однойменними підпроцесами на загальноорганізаційному рівні, як ланок, які знаходяться в сфері загальноорганізаційної відповідальності.

Крім того, пропонований в роботах $[3,6,7]$. підхід до побудови інтегрального показника для багатокритеріального оцінювання виробничої збалансованості $\mathrm{i}$ формування збалансованого виробничого портфеля організацій ДВАТТ, за яким, узгоджуючись із положеннями концепції ДемінгаШухарта, пропонується оцінювати роботу окремих ТОСО відносно кожного із використовуваних часткових показників через «1», якщо значення цього показника не вийшло за контрольні межі за контрольними картами Шухарта, і через «0» - в протилежному випадку, може слугувати для цілей 
розділення формування проектних ініціатив щодо виробничих процесів і систем i, відповідно, портфелів (підпортфелів) виробничих процесів і систем за двома групами - ті, які спрямовані на подолання особливих причин, i ті, які спрямовані на подолання звичайних причин варіацій процесів (підпроцесів), тобто вдосконалення, рис. 2.

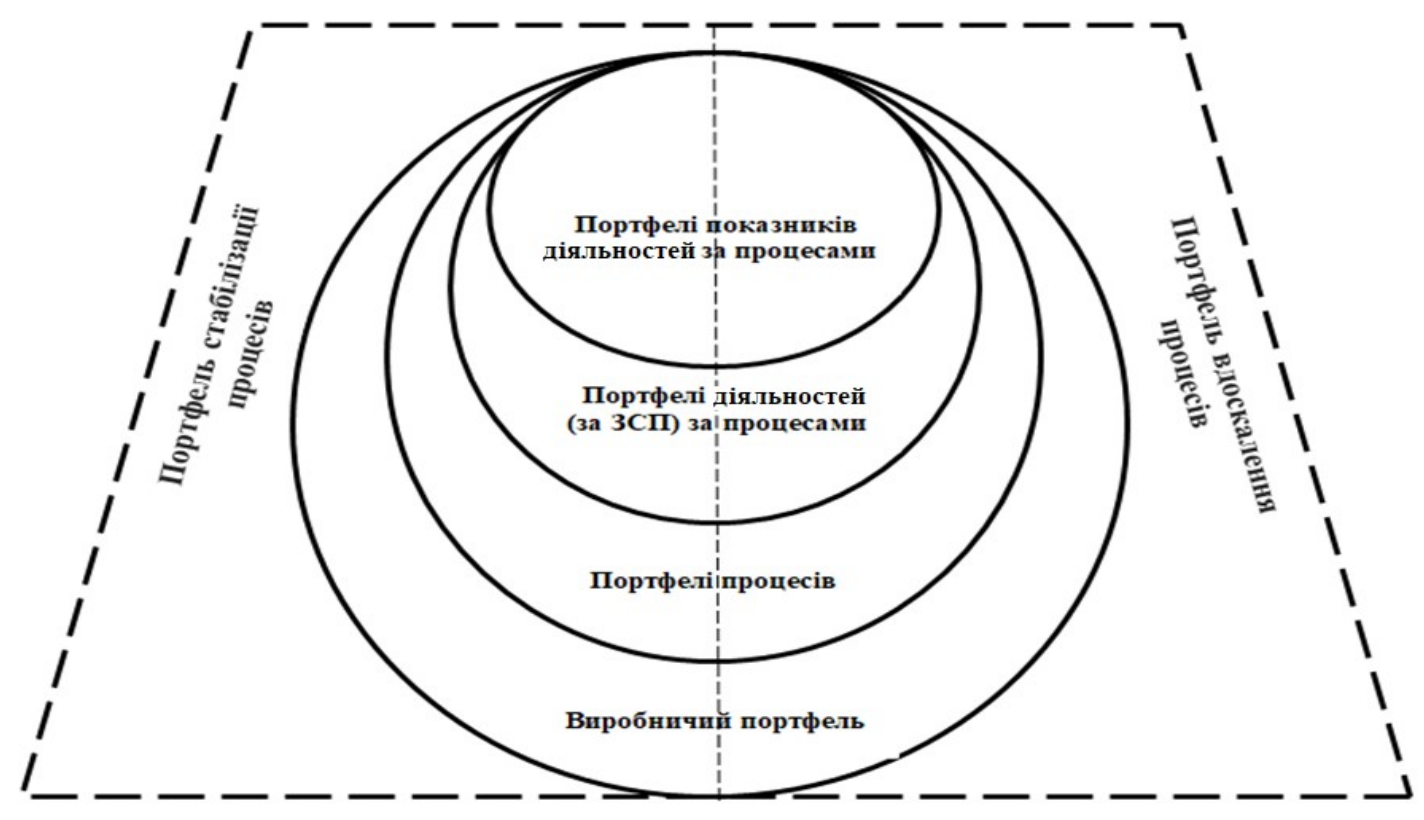

Рисунок 2 - До вибору варіанта структурування портфелів процесів і систем доставки вантажів в організаціях ДВАТТ

Figure 2 - For choosing the option to structure the portfolios of processes and systems of goods delivery in DGRTT organizations

Умови реалізації концепції портфельно-орієнтованого управління збалансованим розвитком процесів і систем доставки вантажів в організаціях ДВАТТ можна описати у вигляді послідовності кроків, як таких, що складають відповідну методику, рис. 3.

Відповідно до стандарту портфельного управління PMI [12] наведений перелік пунктів може розглядатися як основа до формування вихідних даних до такого процесу групи формування портфеля як ідентифікація компонентів. В подальшому можна слідувати діям, які складають процеси портфельного управління за відповідним стандартом РМI.

В контексті впровадження механізму реалізації портфельно-орієнтованого управління збалансованим розвитком організацій ДВАТТ постає потреба в систематизації інформації про проекти і програми, як компоненти - потенційні чи фактичні - щодо портфелів організацій ДВАТТ. На основі даної інформації може вдосконалюватися саме структурування стратегічного портфеля в організації ДВАТТ, зокрема, залежно від дії факторів внутрішнього і зовнішнього середовища, - одні підпортфелі можуть закриватися, інші - виокремлюватися.

Можна запропонувати певну форму до використання при складанні інформаційного довідника про компоненти виробничого портфеля, як портфеля доставки відправлень вантажів, організацій ДВАТТ. Зауважимо, що дана форма не $\epsilon$ альтернативною до загальновідомих шаблонів представлення інформації про проекти, зокрема наведених в роботі [13] та багатьох інших. Це, в більшій мірі, доповнення - як додатковий розділ, який відображає аспекти портфельного управління проектами.

В даному розділі може міститися наступна інформація про компоненти:

- складова щодо групи однорідних ТОСО, до якої відноситься компонент, - вказується, виокремлювана в організації ДВАТТ, група однорідних, за умовами роботи, ТОСО, щодо забезпечення змін в роботі яких передбачається застосування компонента, якщо поділ за групами не проводиться, то така складова відсутня;

- складова щодо окремої ТОСО, на зміни в роботі якої спрямовується компонент;

- складова щодо процесу (підпроцесу), доставки відправлень із використанням термінальної технології, на зміну в якому спрямовується компонент; 
17 Визначити часткові показники за процесами за групами концепції ЗСП оцінювання діяльності організації ДВАТТ

18 Сформувати принципи, обрати методи і розробити процедури для визначення вагових коефіцієнтів за ієрархічними рівнями моделі інтегрального показника (критерію) для оцінювання виробничої збалансованості і формування збалансованого виробничого портфеля організації ДВАТТ

19 Визначити вагові коефіцієнти за ієрархічними рівнями моделі інтегрального показника (критерію) для оцінювання виробничої збалансованості і формування збалансованого виробничого портфеля організації ДВАТТ

20 Визначити проміжні узагальнюючі комплексні показники за моделлю інтегрального показника (критерію) оцінювання виробничої збалансованості і формування збалансованого виробничого портфеля територіальних ЦВ (ТОСО) організації ДВАТТ

21 Визначити інтегральний показник (критерій) за моделлю інтегрального показника (критерію) оцінювання виробничої збалансованості і формування збалансованого виробничого портфеля територіальних ЦВ (ТОСО) організації ДВАТТ

22 Побудувати контрольні картки Шухарта за частковими показниками, визначеними за даними роботи окремих ТОСО (груп однорідних ТОСО) організацій ДВАТТ

23 Визначити, які процеси загального процесу поставки вантажів організацій ДВАТТ знаходяться в стані статистичної керованості

24 Визначити, які ТОСО, за якими процесами загального процесу, які (процеси) потребують стабілізації на рівні організації ДВАТТ, знаходяться поза контрольними межами за контрольними картами Шухарта

25 Провести аналіз причин особливих причин варіації в контексті аналізу роботи окремих ТОСО організацій ДВАТТ щодо однорідності

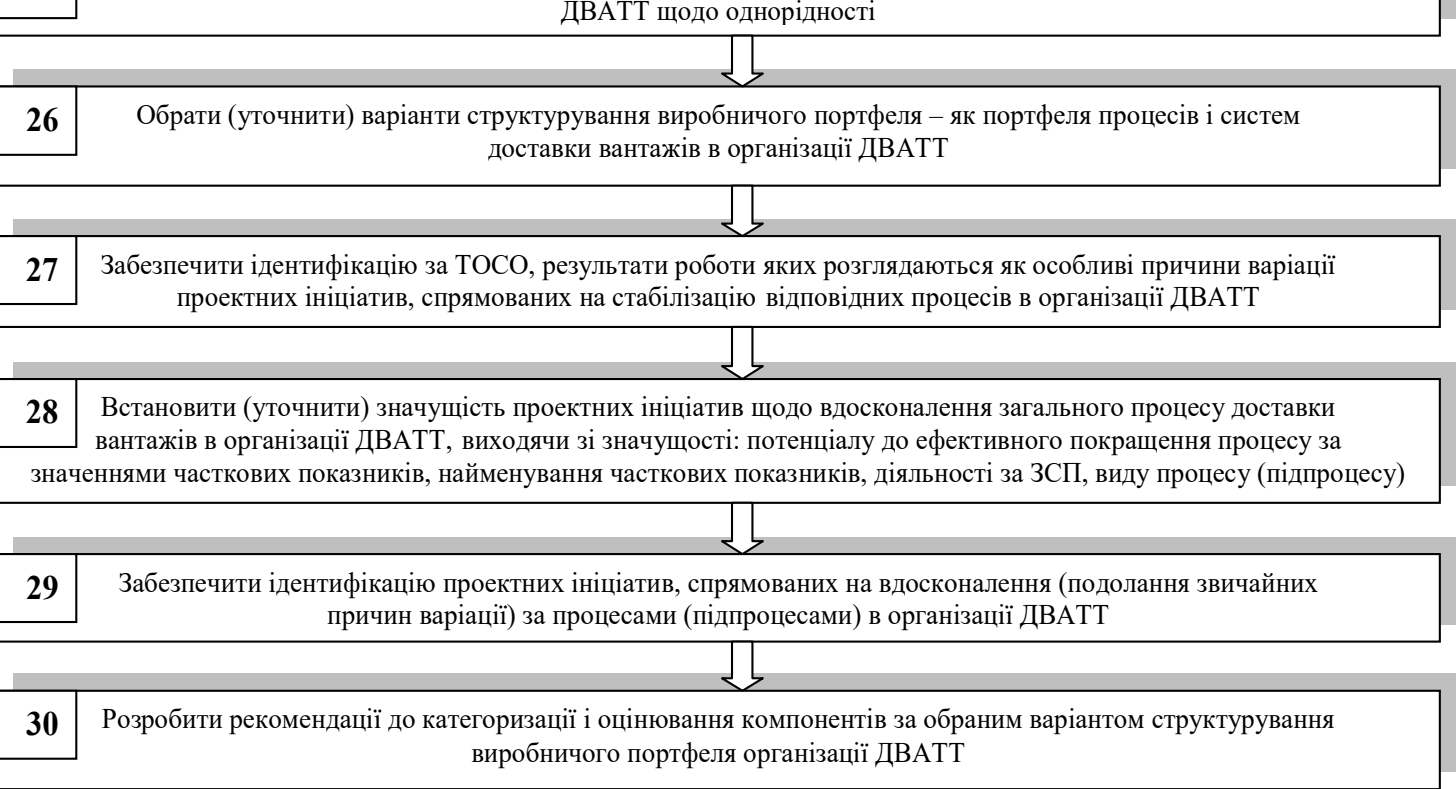

Рисунок 3 - Методика реалізації концепції портфельно-орієнтованого управління збалансованим розвитком процесів і систем доставки вантажів в організаціях ДВАТТ Figure 3 - The methodology for implementation of portfolio management concept of balanced development of processes and systems of goods delivery in DGRTT organizations 
- складова щодо діяльності - клієнти, внутрішні бізнес-процеси, фінансові результати, інновації і навчання та розвиток персоналу - на зміну в якій за відповідним процесом (підпроцесом) спрямовується компонент;

- складова, яка вказує на характер причин, на подолання яких спрямовується компонент особливі причини, тобто передбачається стабілізація процесу, чи звичайні причини, тобто передбачається покращення процесу;

- складова часткових ключових показників діяльності (КПД), за умов невідповідності значень яких ініціюється компонент;

- номер (код) і назва компонента - номер може встановлюватися через надання певних номерів (кодів) окремим групам однорідних ТОСО і/або окремим ТОСО, процесам, діяльностями, КПД - частковим та комплексним. При введені коду КПД може використовуватися нумерація (код) КПД, який той отримав за інформаційним довідником КПД, звичайно, якщо той існує в організації ДВАТТ. При цьому за компоненти портфеля, відповідно до стандарту РМІ [12] можуть виступати проекти, програми, підпортфелі або інші види робіт.

За умов виокремлення в організації ДВАТТ ряду портфелів, як правило, відносно нижчого рівня щодо стратегічного портфеля, тобто підпортфелів, в яких теж можуть виокремлюватися підпортфелі, також постає необхідність в розробленні інформаційних довідників портфелів. Встановлення процедур побудови таких довідників виходить за межі даної роботи, проте портфелі (підпортфелі) із зазначенням номера (коду) портфеля (підпортфеля), який може отримати останній - як за інформаційним довідником портфелів організації ДВАТТ, так і власне, за умов відсутності останнього, за КПД, за яким реалізується компонент, мають зазначатися в додатковому розділі, який має за ціль поєднати компонент із портфелем (підпортфелем), в складі якого компонент реалізується.

Висновок. Запропоновано механізм реалізації портфельно-оріснтованого управління збалансованим розвитком транспортних процесів і систем в організаціях ДВАТТ. В рамках даного механізму сформульовано рекомендації щодо систематизації інформації про проекти і програми - як компоненти портфелів транспортних процесів і систем організації ДВАТТ, а також вибору варіантів структурування даних портфелів.

Подальші дослідження передбачають розвиток запропонованої в роботі концепції портфельноорієнтованого управління збалансованим розвитком виробничих процесів і систем в контексті забезпечення процесів і систем логістичного обслуговування організацій і ланцюгів постачань із урахуванням особливостей впроваджуваних бізнес-моделей.

\section{ПЕРЕЛІК ПОСИЛАНЬ}

1. Білоног О.Є., Третиниченко Ю.О., Системна модель стратегічного управління збалансованим розвитком підприємств, які здійснюють доставку вантажів автомобільним транспортом із використанням термінальної технології // Вісник Національного транспортного університету. Серія «Економічні науки», Науково-технічний збірник. - К.: НТУ, 2017. - Вип.1 (14).

2. Нивен П.Р. Диагностика сбалансированой системы показателей: поддерживая максимальную эффекимвность: Пер. с англ.. - Днепропетровск, «Баланс Бизнес Букс», 2006. - 256с.

3. Третиниченко Ю.О., Халацька I.I. Методичні основи оцінювання збалансованості роботи підприємств автомобільного транспорту // Наукові записки Інституту законодавства Верховної Ради України. - К.: Інститут законодавства Верховної Ради України, 2017. - Вип 6. С. 146-152.

4.Деминг Э. Выход из кризисна: Новая парадигма управления людьми, системами и процессами: Пер.с англ. - 4-е изд. - М.: Альпина Паблишер, 2011. - 415 с.

5. Статистичний контроль. Контрольні карти Шухарта (ISO 8258:1991, IDT): ДСТУ ISO 8258:2001. - К.: Держспоживстандарт України, 2003. - 32c. - (Національний стандарт України)

6. Воркут Т.А., Третиниченко Ю.О., Халацька І.І. Модель формування інтегрального показника для оцінювання збалансованості функціонування та розвитку мережевих організаційних структур перевізників автомобільного транспорту із урахування варіабельності процесів // Управління проектами, системний аналіз і логістика. 2017. № 19. С. 14-20.

7. Срібна Н.В., Третиниченко Ю.О., Халацька І.І. Оцінювання збалансованості роботи підприємств перевізників автомобільного транспорту. Транспорт і логістика: проблеми та рішення: мат. VIII Міжн. наук.-практ. конф., Сєвєродонецьк - Одеса - Вільнюс - Київ, (23-25 травня 2018, м. Одеса) Одеса, 2018. С. 214-216.

8. Илларионов А. В., Клименко Э. Ю. Портфель проектов: Инструмент стратегического управления предприятием. М. : Альпина Паблишер, 2013. С. 312. 
9. Boyson S., Corsi T., Dresner M., Rabinovich E. Managing effective third party logistics relationships: what does it take? // Journal of Business Logistics. №1, vol. 20, 1999. P. 73-100.

10. Lambert D. M., Emmelhainz M. A., Gardner J. T. Building successful logistics partnership // Journal of Business Logistics, №1, vol. 20, 1999. P. 165-182.

11. Ламберт Д., Немейер М. Партнерство - дело общее // В сборник. Как организовать цепочку поставок (Harvard Business Review on Supply Chain Management) / пер. с англ. Москва : Альпина Бизнес Букс, 2008. 207 c.

12. Project Management Institute. 2017. The Standard for Portfolio Management - Fourth Edition. Newtown Square, PA: PMI.

13. Ципес Г. Л., Товб А. С. Проекты и управление проектами в современной компании. Учебное пособие М. : ЗАО «Олимп-Бизнес», 2009. 480 с.

14. Gittinger J. P. Economic Analysis of Agricultural Projects. Baltimore : The Johns Hopkins University Press, 1982.

\section{REFERENCES}

1. Bilonog O.Ye., Tretynychenko Yu.A. (2017). Systemna model' stratehichnoho upravlinnia zbalansovanym rozvytkom pidpryyemstv, yaki zdiysnyuyut' dostavku vantazhiv avtomobil'nym transportom iz vykorystannyam terminal'noyi tekhnolohiyi [The system model of strategic management of sustainable development of enterprises that goods delivery by road using terminal technology]. Kyiv: NTU [ in Ukrainian].

2. Paul R. Niven (2006). Diahnostyka sbalansyrovannoy systemy pokazateley: Podderzhyvaya maksymal'nuyu effektyvnost'[Balanced Scorecard Diagnostics: Maintaining Maximum Performance]. Dnepropetrovsk: «Balance Business Books» [in Russian].

3. Tretynychenko Y.A., Khalatska I.I. (2017). Metodychni osnovy otsiniuvannia zbalansovanosti roboty pidpryiemstv avtomobilnoho transport [Methodical fundamentals of evaluation of the balanced perfomance of road transport enterprises]. Kyiv: Institute of Law of Verhovna Rada of Ukraine [in Ukrainian].

4. Deming E. (2011). Vyhod iz krizisa. Novaya paradigma upravleniya liudmi, sistemami i protsessami [Out of the crisis. A new paradigm of managing people, systems and processes]. M.: Alpina Publisher [in Russian].

5. Statystychnyi kontrol. Kontrolni karty Shukharta (2003) (ISO 8258:1991, IDT): DSTU ISO 8258:2001 [Statistical control. Control cards of Scuhart (ISO 8258:1991, IDT): DSTU ISO 8258:2001]. K.: Derzhspozhyvstandart of Ukraine. National standard of Ukraine [in Ukrainian].

6. Vorkut T.A., Tretynychenko Y.O., Khalatska I.I. (2017). Model formuvannia intehralnoho pokaznyka dlia otsiniuvannia zbalansovanosti funktsionuvannia ta rozvytku merezhevykh orhanizatsiinykh struktur pereviznykiv avtomobilnoho transportu iz urakhuvannia variabelnosti protsesiv [The model of the integral indicator elaboration for evaluation of sustainable functioning and development of organizational networking structures of road transport companies taking into account processes variability]. Kyiv: NTU [in Ukrainian].

7. Sribna N.V., Tretynychenko Y.A., Khalatska I.I. (2018). Otsiniuvannia zbalansovanosti roboty pidpryiemstv pereviznykiv avtomobilnoho transportu. [The evaluation of balanced performance of road transport companies]. Odesa [in Ukrainian].

8. Illarionov A.V., Klimenko E.Yu. (2013). Portfel proektov: Instrument stratehicheskoho upravlenyia predpryiatiyem [Project portfolio: The instrument of strategic management of an enterprise]. M.: Alpina Publisher [in Russian].

9. Boyson S., Corsi T., Dresner M., Rabinovich E. (1999). Managing effective third party logistics relationships: what does it take? [Journal of Business Logistics].

10. Lambert D. M., Emmelhainz M. A., Gardner J. T. (1999). Building successful logistics partnership [Journal of Business Logistics].

11. Lambert D.M. Neimeyer M.A. (2008). Partnerstvo - delo obshchee. V sbornik. Kak organizovat tsepochku postavok. [A partnership is a common business. How to organize supply chain. Harvard Business Review on Supply Chain Management]. M.: Alpina Publisher [in Russian].

12. Project Management Institute. (2017). The Standard for Portfolio Management - Fourth Edition. Newtown Square, PA: PMI.

13. Tsypes H. L., Tovb A. S. (2009). Proekty i upravleniye proektami v sovremennoi kompanii [Project and project management in a modern company]. M.: ZAO «Olimp-Business» [in Russian].

14. Gittinger J. P. (1982). Economic Analysis of Agricultural Projects. Baltimore: The Johns Hopkins University Press. 


\section{PЕФЕРАТ}

Білоног О.Є. Механізм реалізації портфельно-орієнтованого управління збалансованим розвитком організацій перевізників автомобільного транспорту / О.Є. Білоног, Ю.О. Третиниченко, Н.В. Срібна, П.Г. Параніч // Вісник Національного транспортного університету. Серія «Економічні науки». Науково-технічний збірник. - К. : НТУ, 2020. - Вип. 2 (47).

В статті розроблено механізм реалізації портфельно-орієнтованого управління збалансованим розвитком організацій перевізників автомобільного транспорту.

Об'єкт дослідження - процес управління підприємствами ДВАТТ.

Мета роботи - розроблення механізмів реалізації методичних основ формування інтегрального показника для багатокритеріального оцінювання збалансованості роботи підприємств ДВАТТ.

Метод дослідження - метод аналізу та синтезу, метод аналогії та порівнянь.

На основі концепції портфельного управління збалансованим розвитком виробничих процесів і систем, як процесів і систем доставки вантажів, в організаціях ДВАТТ, які розглядаються як мережа однорідних організаційних одиниць, пов'язаних між собою умовами реалізації використовуваної технології, запропоновано механізм реалізації портфельно-орієнтованого управління збалансованим розвитком організацій перевізників автомобільного транспорту.

КЛЮЧОВІ СЛОВА: ПОРТФЕЛЬНО-ОРІЕНТОВАНЕ УПРАВЛІННЯ; ЗБАЛАНСОВАНИЙ РОЗВИТОК; ПІДПРИСМСТВА, ЯКІ ЗДІЙСНЮЮТЬ ДОСТАВКУ ВАНТАЖІВ АВТОМОБІЛЬНИМ ТРАНСПОРТОМ ІЗ ВИКОРИСТАННЯМ ТЕРМІНАЛЬНОЇ ТЕХНОЛОГІЇ; ТЕРИТОРАЛЬНІ ОРГАНІЗАЦІЇ СТРУКТУРНИХ ОДИНИЦЬ, ІНТЕГРАЛЬНИЙ ПОКАЗНИК.

\section{ABSTRACT}

Bilonog O.Ye., Tretynychenko Yu.A., Sribna N.V., Paranich P.H. The implementation mechanism for portfolio management of the balanced development of road transport companies. Visnyk National Transport University. Series «Economic sciences». Scientific and Technical Collection. - Kyiv: National Transport University, 2020. - Issue 2 (47).

In the article the authors designed the implementation mechanism for portfolio management of the balanced development of road transport companies.

The object of the research is the management process of the DGRTT enterprises.

The purpose of the paper is to design the implementation mechanisms for methodical fundamentals of an integral indicator formation for multi-criteria assessment of the balanced work of the DGRTT enterprises.

The method of research - the method of analysis and synthesis, the method of analogy and comparisons.

On the basis of portfolio management concept of balanced development of production processes and systems, as the processes and systems of cargo delivery, in DGRTT organizations, which are considered as a network of homogeneous organizational units connected by the implementation conditions of the applied technology, the authors propose the implementation mechanism for portfolio management of the balanced development of road transport companies.

KEY WORDS: PORTFOLIO MANAGEMENT, BALANCED DEVELOPMENT, ENTERPRISES IMPLEMENTING DELIVERY OF GOODS BY ROAD USING TERMINAL TECHNOLOGY; TERRITORIAL ORGANIZATIONS OF STRUCTURAL UNITS, INTEGRAL INDICATOR.

\section{РЕФЕРАТ}

Билоног О.Е. Механизм реализации портфельно-ориентированого управления сбалансированным развитием организаций перевозчиков автомобильного транспорта/ О.Е. Билоног, Ю.О. Третиниченко, Н.В. Срибна, П.Г. Паранич // Вестник Национального транспортного университета. Серия «Экономические науки». Научно-технический сборник. - К.: НТУ, 2020. - Вып. 2 (47).

В статье разработан механизм реализации портфельно-ориентированого управления сбалансированным развитием организаций перевозчиков автомобильного транспорта.

Объект исследования - процесс управления предприятиями ДГАТТ.

Цель работы - разработка механизмов реализации методических основ формирования интегрального показателя для многокритериального оценивания сбалансированности работы предприятий ДГАТТ.

Метод исследования - метод анализа и синтеза, метод аналогии и сравнения.

На основании концепции портфельного управления сбалансированным развитием производственных процессов и систем, как процессов и систем доставки грузов, в организациях ДГАТТ, которые рассматриваются как сеть однородных организационных единиц, связанных между собой условиями реализации использованной технологии, предложено механизм реализации 
портфельно-ориентированого управления сбалансированным развитием организаций перевозчиков автомобильного транспорта.
КЛЮЧЕВЫЕ
СЛОВА:
ПОРТФЕЛЬНО-ОРИЕНТИРОВАНОЕ
УПРАВЛЕНИЕ; СБАЛАНСИРОВАННОЕ РАЗВИТИЕ; ПРЕДПРИЯТИЯ, КОТОРЫЕ ОСУЩЕСТВЛЯЮТ ДОСТАВКУ ГРУЗОВ АВТОМОБИЛЬНЫМ ТРАНСПОРТОМ С ИСПОЛЬЗОВАНИЕМ ТЕРМИНАЛЬНОЙ ТЕХНОЛОГИИ; ТЕРРИТОРТАЛЬНЫЕ ОРГАНИЗАЦИИ СТРУКТУРНИХ ЕДИНИЦ, ИНТЕГРАЛЬНЙЙ ПОКАЗАТЕЛЬ.

\section{АВТОРИ:}

Білоног Оксана Євгенівна, Національний транспортний університет, e-mail: bilonog.oksana@gmail.com, тел. +380442544326, Україна, 01010, м. Київ, вул. М. ОмеляновичаПавленка 1, к. 439, orcid.org/0000-0003-2471-5388

Третиниченко Юрій Олександрович, Національний транспортний університет, e-mail: tpsalkaf@ntu.edu.ua,тел. +380442544326, Україна, 01010, м. Київ, вул. М. Омеляновича-Павленка 1, к. 439, orcid.org/0000-0002-3797-9035

Срібна Наталія Василівна, Національний транспортний університет, e-mail: natasribna28@gmail.com, тел. +380442544326, Україна, 01010, м. Київ, вул. М. Омеляновича-Павленка 1, к. 439, orcid.org/0000-0002-7543-2997

Параніч Поліна Геннадіївна, Національний транспортний університет, e-mail: pparanich@ukr.net, тел. +380442544326, Україна, 01010, м. Київ, вул. М. Омеляновича-Павленка 1, к. 439, orcid.org/00000002-1029-3535

\section{AUTHORS:}

Bilonog Oksana Yevhenivna., National Transport University, e-mail: bilonog.oksana@gmail.com, tel: +380442544326, Ukraine, 01010, Kyiv, M. Omelianovycha-Pavlenka str.1, of. 439, orcid.org/0000-0003$2471-5388$

Tretynychenko Yuriy Oleksandrovych, National Transport University, e-mail: tpsalkaf@ntu.edu.ua, tel: +380442544326, Ukraine, 01010, Kyiv, M. Omelianovycha-Pavlenka str.1, of. 439, orcid.org/0000-00023797-9035

Sribna Nataliia Vasylivna, National Transport University, e-mail: natasribna28@gmail.com, tel: +380442544326, Ukraine, 01010, Kyiv, M. Omelianovycha-Pavlenka str.1, of. 439, orcid.org/0000-00027543-2997

Paranich Polina Hennadiivna, National Transport University, e-mail: pparanich@ukr.net, tel: +380442544326 , Ukraine, 01010, Kyiv, M. Omelianovycha-Pavlenka str.1, of. 439, orcid.org/0000-0002$1029-3535$

\section{АВТОРЫ:}

Билоног Оксана Евгенивна, Национальный транспортный университет, e-mail: bilonog.oksana@gmail.com, тел. +380442544326, Украина, 01010, м. Киев, ул. М. ОмельяновичаПавленка 1, к. 439, orcid.org/0000-0003-2471-5388

Третиниченко Юрий Александрович, Национальный транспортный университет, e-mail: tpsalkaf@ntu.edu.ua, тел. +380442544326, Украина, 01010, м. Киев, ул. М. Омельяновича-Павленка 1, к. 439, orcid.org/0000-0002-3797-9035

Срибна Наталия Васильевна, Национальный транспортный университет, e-mail: natasribna28@gmail.com, тел. +380442544326, Украина, 01010, г. Киев, ул. М. Омельяновича-Павленка 1, к. 439, orcid.org/0000-0002-7543-2997

Паранич Полина Геннадиевна, Национальный транспортный университет, e-mail: pparanich@ukr.net, тел. +380442544326, Украина, 01010, м. Киев, ул. М. Омельяновича-Павленка 1, к. 439, orcid.org/0000-0002-1029-3535

\section{РЕЦЕНЗЕНТИ:}

Воркут Т.А., доктор технічних наук, професор, Національний транспортний університет, завідувачка кафедри транспортного права та логістики, Київ, Україна.

Гурнак В.М., доктор економічних наук, професор, Національний транспортний університет, професор кафедри транспортного права та логістики, Київ, Україна.

\section{REVIEWER:}

Vorkut T.A. Dr., Professor, National Transport University, Head of Transport Law and Logistics Department, Kyiv, Ukraine.

Hurnak V.M., Dr., Professor, National Transport University, Professor of Transport Law and Logistics Department, Kyiv, Ukraine. 